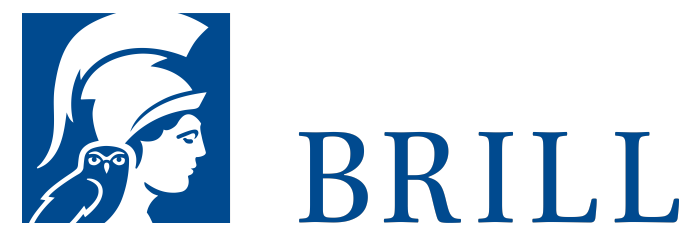

\title{
Objektivität und Moral
}

Ein problemgeschichtlich-systematischer Beitrag zur neueren Realismusdebatte in der Metaethik

Author: Markus Rüther

In diesem Buch wird eine lange vernachlässigte Position in der Metaethik verteidigt - der sogenannte moralische Realismus. Demnach existieren moralische Tatsachen, die moralische Urteile als wahr oder falsch ausweisen. Diese Tatsachen werden jedoch nicht dadurch konstituiert, dass jemand (eine Person, eine Gesellschaft oder eine Kultur) behauptet, dass sie existieren. Es handelt sich bei ihnen um einen eigenständigen Bestandteil der Wirklichkeit, wenngleich sie etwas anderes als naturwissenschaftliche Tatsachen sind. Moralische Tatsachen sind nicht nur objektiv, sondern auch intrinsisch normativ und motivational wirksam. Folgt daraus aber nicht eine Wiedereinführung eines obskuren Reichs der Werte? Diese Frage wird vom Autor verneint und im Rahmen einer Kritik an gängigen Naturalisierungsstrategien in der Metaethik plausibilisiert. In konstruktiver Hinsicht wird schließlich ein sogenannter expansiver Naturalismus expliziert, auf dessen Basis der moralische Realismus vertreten werden kann.

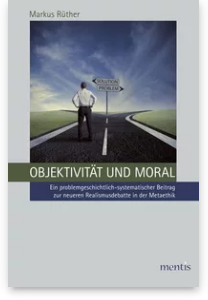

Pages: 262

Seiten

Language:

German

Subjects:

General,

Philosophy

Publisher: Brill | mentis

E-Book (PDF)

Released online:

o1 Jun 2013

ISBN: $978-3^{-}$

89785-977-7

List price

Paperback

Publication date:

o1 Jun 2013

ISBN: 978-3-

89785-830-5

List price 
For more information see brill.com

Order information: Order online at brill.com +44330 333 0049 | customerservices@brill.com Submission information: brill.com/authors

Titles published by Brill | Fink, Brill | mentis or Brill | Schöningh: +49(o)715413279216| brill@brocom.de 